\title{
ENRICHING NUTRITIVE VALUE OF CASSAVA ROOT BY YEAST FERMENTATION
}

\author{
Krisada Boonnop ${ }^{1}$; Metha Wanapat ${ }^{1 *}$; Ngarmnit Nontaso²; Sadudee Wanapat ${ }^{3}$ \\ ${ }^{1}$ Khon Kaen University/Faculty of Agriculture/Tropical Feed Resources Research and Development Center - \\ Dept. of Animal Science, Khon Kaen, 40002 Thailand. \\ ${ }^{2}$ Khon Kean University/Faculty of Science - Dept. of Microbiology. \\ ${ }^{3}$ Khon Kaen University/Faculty of Agriculture - Dept. of Plant Science and Natural Resources. \\ *Corresponding author <metha@kku.ac.th>
}

\begin{abstract}
Cassava (Manihot esculenta) is extensively cultivated throughout the tropics and subtropics regions due to its ability to grow in diverse soil conditions and minimal management. Experiments were made to study the cassava root fermentation by yeasts in order to enhance the nutritive value of their products (fresh pulp and chips). Both cassava chip (CC) and fresh cassava root pulp (FCR) samples were fermented by Saccharomyces cerevisiae in solid-liquid media fermentation conditions during 132 hours and dried at $30^{\circ} \mathrm{C}$. Products were analyzed for proximate composition, mineral composition, essential aminoacids and antinutrient content. There were increases $(p<0.01)$ in protein (30.4\% in CC and $13.5 \%$ in fermented cassava root -FCR) and fat contents (5.8\% in CC and $3.0 \%$ in FCR). S. cerevisiae fermented cassava products had very low hydrocyanic acid (HCN) contents (CC, $0.5 \mathrm{mg} \mathrm{kg}^{-1}$ and FCR, $47.3 \mathrm{mg} \mathrm{kg}^{-1}$ ). There was a remarkable increase in lysine content in the fermented cassava chip (FCC). The best acceptability and organoleptic attributes (color, texture and aroma) of enriched cassava chip were achieved after 132h of bioprocessing. The results of this study suggest that FCC can be nutritionally improved with $S$. cerevisiae for animal feeding.

Key words: Saccharomyces cerevisiae, fermentation, cassava chip, fresh cassava root pulp, protein, animal feed

\section{ENRIQUECIMENTO DO VALOR NUTRITIVODAMANDIOCA POR FERMENTAÇÃO COM LEVEDURAS}

\begin{abstract}
RESUMO: A mandioca (Manihot esculenta) é extensivamente cultivada nas regiões tropical e subtropical devido à sua habilidade de crescer em diveresas condições de clima e manejo. Experimentos foram efetuados para estudar o aumento do valor nutritivo de subprodutos derivados de raízes de mandioca (polpa fresca e raspas) por processos de fermentação. Amostras de raspas (RM) e de polpa fresca (PF) foram fermentadas por Saccharomyces cerevisiae, em condições de meio sólido-líquido durante 132 horas e secas a $30^{\circ} \mathrm{C}$. Foram avaliados a composição aproximada, composição mineral, aminoácidos essenciais e conteúdo de antinutrientes dos produtos obtidos. Houve aumentos ( $p<$ 0.01) em proteínas (30,4\% em RM e 13,5\% in PF) e conteúdo de gorduras (5,8\% em RM e 3,0\% in PF). Os subprodutos de mandioca fermentados por $S$. cerevisiae apresentaram baixos conteúdos de ácido

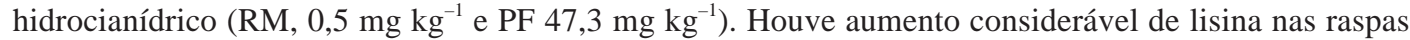
fermentadas (RMF). Valores aceitáveis de cor, textura e aroma das raspas de mandioca enriquecidas formam obtidos após 132 de bioprocessamento. Sugere-se que a RMF pode ser nutricionalmente melhorada para alimentação animal pelo uso de $S$. cerevisiae.

Palavras chave: Saccharomyces cerevisiae, fermentação, raspas de mandioca, polpa fresca de mandioca, proteína, nutrição animal.
\end{abstract}

\section{INTRODUCTION}

Cassava (Manihot esculenta, Crantz) is extensively cultivated throughout the tropics and subtropics regions due to its ability to grow in diverse soil conditions and minimal management (Wanapat, 2003; Wanapat et al. 2006; Wanapat \& Khampa, 2007). The root is composed almost entirely of carbohydrate which can be used as important food source. However, it contains cyanogens (1- 3\% CP) depending on cultivars (Stupak et al., 2006) and large amount of cyanogenic glucosides in the cassava flour (Cumbana et al., 2007) which could limit cassava root utilization for consumption and for livestock feeding. The laminarin and lotaustralin cassava's cyanogenic compounds are changed to hydrocyanic acid (HCN) by the action of the laminarase enzyme when roots are crushed or sliced (Wanapat et al., 1999; Cardoso et al., 2005). The common process 
of cassava root sun drying does not sufficiently remove the cyanide content. Bradbury (2006) and Cumbana et al. (2007) reported that the total cyanide content in cassava flour was reduced to three or six folds when soaking in water in an open vessel for 5 hours at $\left(30^{\circ} \mathrm{C}\right)$. The process of protein enrichment of animal feed using the microorganisms in a semisolid culture to improve the nutritional value of the forage palm for ruminants feeding has been evaluated (Araujo et al, 2008; Vendruscolo et al, 2009). Fermentation of cassava peels by pure culture of $S$. cerevisiae could increase its protein content from $(2.4 \%)$ in nonfermented cassava to (14.1\%) in fermented products (Antai \& Mbongo, 1994). The fermented cassava flour with $S$. cerevisiae enhanced the protein level (from $4.4 \%$ to $10.9 \%$ ) and decreased the amount of cyanide content (Oboh \& Kindahunsi, 2005). The objective of this study is to investigate enrichment of cassava root pulp and chip by fermentation using $S$. cerevisiae for animal feeding.

\section{MATERIALAND METHODS}

\section{Material}

Cassava roots used in these experiments were freshly harvested from the field. The commercial baker yeast (Sacchromyces cerevisiae), manufactured by Berly Speciality Industries, Company Limited, Bangkok, Thailand was used in the fermentation processes. Commercial grade urea and sugar cane molasses were purchased from the local shop.

\section{Yeast inoculants preparation}

Baker yeast was cultured in the cylinder vessels which contained solution of $20 \%$ molasses (w/v) and $4 \%$ urea $(\mathrm{w} / \mathrm{v})$. The products were incubated at room temperature and oxygen was supplied by an air pump for $60 \mathrm{~h}$.

\section{Sample preparation}

A completely randomized design (CRD) with a 2 $\times 2$ factorial arrangement of treatments was used. The model included cassava source, method of fermentation and their interactions as fixed effects, and experimental run as random effects. Treatments were: (i) unfermented cassava chip (UFCC), (ii) fermented cassava chip (FCC), (iii) unfermented fresh cassava root pulp (UFCR), and (iv) fermented fresh cassava root pulp (FFCR). There were three replicates for each treatment. In the second and fourth treatments, CC and FCR were washed, grated, after which $100 \mathrm{~g}$ of processed pulp was spread on a tray (about $50 \mathrm{~cm}$ diameter) to an average layer thickness of $2 \mathrm{~cm}$. Yeast inoculum was mixed and inoculated into $0.5 \mathrm{~kg}$ of the mash (CC and FCR) as the starter and $250 \mathrm{~mL}$ nutrient solution [urea (48 g) and molasses (24 g)] were added. Fermentation was conducted during 132 hours at $25^{\circ} \mathrm{C}$ under an air relative humidity between $40 \%$ and $50 \%$. The first and third treatments were unfermented cassava mash, which served as the control. Both the fermented and unfermented cassava mash were sun-dried for three days at a $30^{\circ} \mathrm{C}$ average temperature and milled into yeast fermented cassava products as presented in Figures 1 and 2.

\section{Chemical analysis}

Dry matter (DM) of yeast fermented and non fermented cassava products were analyzed for DM by drying at $105 \mathrm{C}$ for $12 \mathrm{~h}$ in a forced air oven, ash and nitrogen contents were determined by micro-Kjeldahl method (AOAC, 1997). Attempts were also made to calculate the amount of solubilized protein- $\mathrm{N}$ in each extraction by using the Lowry procedure (Lowry et al., 1951). The samples were also analyzed for neutral-detergent fiber (NDF) and acid-detergent fiber (ADF) (Soest et al., 1994). One of the $5 \mathrm{~mL}$ samples were used for cyanide concentration measurement by spectrophotometrical (SpectroSC, LaboMed, inc. USA) with the 2, 4-quinolinediol-pyridine reagent (Lambert et al., 1975). The mineral (Ca and P) contents were determined on aliquots of the solutions of the ash by established flame atomic absorption spectrophotometry procedures using a Perkin-Elmer atomic absorption spectrophotometer. Amino acids were determined spectrophotometrically according to procedure of Chinhard (1952).

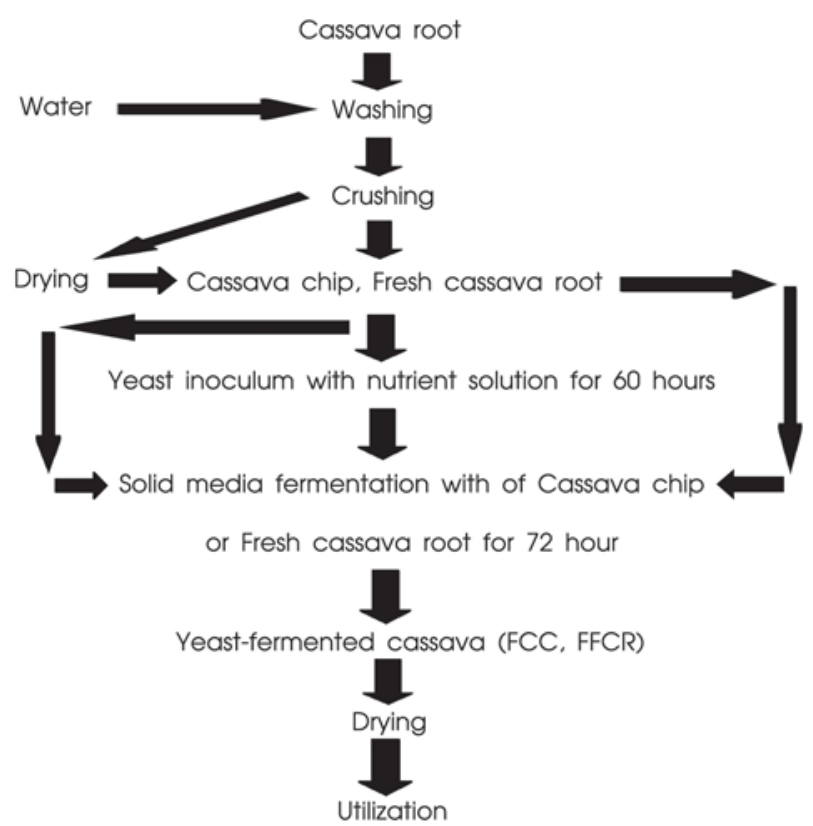

Figure 1 - Production chart for yeast fermented cassava products. 


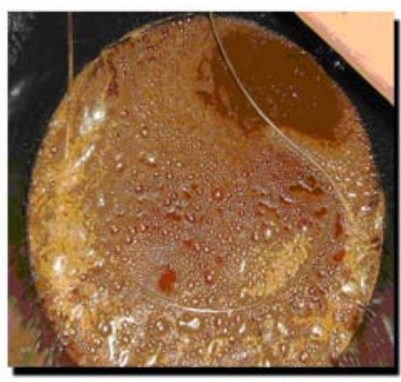

Yeast inoculum with nutrient

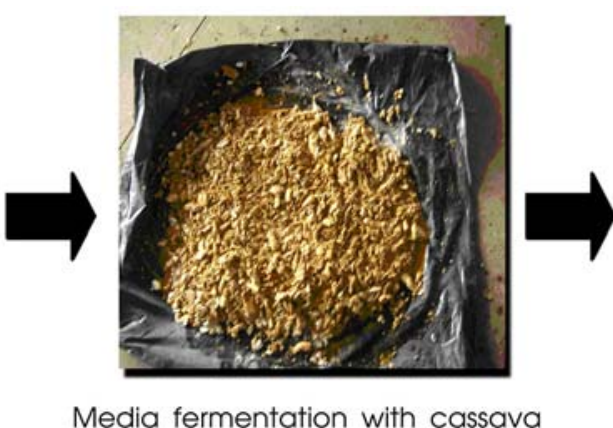

Media fermentation with cassava

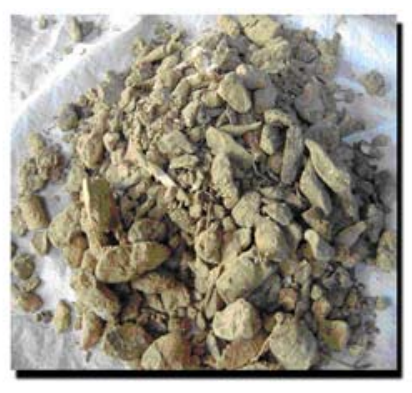

FCC and FFCR products

Figure 2 - Production chart for fermentation of cassava with Saccharomyces cerevisae.

\section{Analysis of data}

All data were statistically analyzed using the analysis of variance of a completely randomized design with a $2 \times 2$ factorial arrangement of treatments (cassava source and method of fermentation) using the GLM procedure (SAS, 1988). Treatment means were statistically compared using Duncan's New Multiple Range Test.

\section{RESULTS AND DISCUSSION}

The cassava fermentation products had brownish color and good aroma after sun-drying (Figures 1 and 2). DM of FCC and FCR were $85.3 \%$ and $65.7 \%$, respectively and the mean protein value of $S$. cerevisiae fermented cassava products, FCR and CC were 18.9\% and $30.4 \%$, respectively (Table 1 ). They were remarkably higher when in comparison to unfermented cassava products. The increase in growth and proliferation of the fungi or bacterial complex in the form of single cell proteins may possibly account for the apparent increase in the protein content as also found by Antai \& Mbongo (1994); Oboh (2002). Moreover, Correia et al. (2007) reported that $S$. cerevisiae was assessed to increase protein levels of pineapple waste (PW) by solid state bioprocessing (SSB) with and without nitrogen supplementation while PW (10 g) was inoculated with $S$. cerevisiae. Optimum protein content ( $22 \%$ dry basis), which is 3.5 -fold of the original protein content, reached at $48 \mathrm{~h}$ of incubation when $0.25 \%$ $\left(\mathrm{NH}_{4}\right)_{2} \mathrm{SO}_{4}$ was added to the medium. This high protein content could be attributed to the ability of the $S$. cerevisiae to secrete some extracellular enzymes such as amylases, linamarase and cellulase into the cassava mash during their metabolic activities, which would lead to yeast growth (Oboh \& Akindahunsi, 2003). The protein content of the product (Table 1) was similar to the products fermented with S. cerevisiae and Lactobacillus spp. in solid media using cassava peels (Oboh, 2006). This high protein cassava product could very well serve as a protein source in animal diets provided it is economically viable.
Fat content of FCR and CC increased $(p<0.01)$ after fermentation. The reason for the unusually high fat content increase could not be yet well explained. However, it could partly be attributed from cell increase of the fermentation. In addition, there could be possible transformation of carbohydrate to fat as occurred in Leuconostoc mesenteriodes (Padmaja et al., 1993) to be highly lipolytic. In fact, this highly lipolytic microorganism was able to hydrolyse $5 \%$ olive oil added to yeast agar medium. Similar result was found in cassava fermentation by Fagbemi \& Ijah (2006). Akindumila \& Glatz (1998) reported that certain fungi can produce microbial oil during fermentation. The decrease in carbohydrate could be attributed to the possible transformation of some of the carbohydrate, which could be used as carbon sources for synthesis of protein or fat (Lehninger, 1987). However, there was a substantial increase in lipid constituent of the fermenting cassava mash that had been previously inoculated. This increase was a result of the growth of yeast cells added as inocula to the cassava mash. However, there was no changes in NDF, ADF and OM contents of the fermented cassava products.

Increases in protein content have been obtained in the fermented products (Tables 1 and 2). In addition, there was a decrease in the HCN content when compared with the unfermented cassava products. Levels of the residual cyanide present in both FCR $(47.3 \mathrm{mg}$ $\left.\mathrm{kg}^{-1}\right)$ and CC (0.5 $\left.\mathrm{mg} \mathrm{kg}^{-1}\right)$ were remarkably low when compared with the normal cyanide content of the unfermented cassava. These levels were considered safe for animal feeding. Oboh et al. (2002) and Oboh \& Akindahunsi (2003) found that cyanide concentration in the cassava peels fermented with waste-water from fermented cassava pulp was low, when compared with the normal cyanide content of cassava products in $\mathrm{Ni}$ geria [19.0 $\mathrm{mg} \mathrm{kg}^{-1}$ (gari), $25 \mathrm{mg} \mathrm{kg}^{-1}$ (fufu)], and with that of the cyanide content of some micro-fungi fermented cassava products (9.1-17.2 $\mathrm{mg} \mathrm{kg}^{-1}$ ). This suggest that baker's yeast is capable of utilizing cyanogenic glycosides and the breakdown products, thus explaining why it is one of the natural flora involved 
Table 1 - Chemical composition and nutritive value of fermented cassava products (\%DM).

\begin{tabular}{|c|c|c|c|c|c|}
\hline \multirow{2}{*}{ Item } & \multicolumn{2}{|c|}{$\mathrm{CC}^{1}$} & \multicolumn{2}{|c|}{$\mathrm{FCR}^{2}$} & \multirow{2}{*}{$\mathrm{SEM}^{7}$} \\
\hline & $\mathrm{UCC}^{3}$ & $\mathrm{FCC}^{4}$ & $\mathrm{UFCR}^{5}$ & $\mathrm{FFCR}^{6}$ & \\
\hline DM & $89.4^{a}$ & $85.3^{\mathrm{a}}$ & $68.9^{\mathrm{b}}$ & $65.7^{b}$ & 1.95 \\
\hline $\mathrm{OM}$ & 95.8 & 97.6 & 95.9 & 96.2 & 0.88 \\
\hline $\mathrm{CP}$ & $3.4^{\mathrm{a}}$ & $32.5^{b}$ & $3.2^{\mathrm{a}}$ & $21.1^{\mathrm{c}}$ & 1.2 \\
\hline NPN & $0.2^{\mathrm{a}}$ & $2.1^{\mathrm{b}}$ & $0.3^{\mathrm{a}}$ & $2.2^{b}$ & 0.15 \\
\hline $\mathrm{TP}^{8}$ & $3.2^{\mathrm{a}}$ & $30.4^{b}$ & $2.8^{\mathrm{a}}$ & $18.9^{c}$ & 0.11 \\
\hline Fat & $2.7^{\mathrm{a}}$ & $5.8^{b}$ & 2.3 & $3.0^{\mathrm{a}}$ & 0.02 \\
\hline NDF & 7.7 & 7.3 & 7.8 & 7.5 & 0.04 \\
\hline $\mathrm{ADF}$ & 6.1 & 5.8 & 6.2 & 6.0 & 0.05 \\
\hline
\end{tabular}

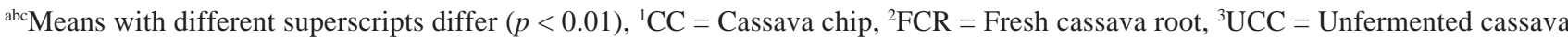
chip, ${ }^{4} \mathrm{FCC}=$ Fermentated cassava chip, ${ }^{5} \mathrm{UFCR}=$ Unfermented fresh cassava root, ${ }^{6} \mathrm{FFCR}=$ Fermented fresh cassava root pulp, ${ }^{7}$ Standard error of the mean, ${ }^{8}$ True protein $=$ Crude protein $\left.(\mathrm{CP})-\mathrm{NPN}\right)$

Table 2 - Cyanide, lysine, Ca and P contents of fermented cassava products.

\begin{tabular}{|c|c|c|c|c|c|}
\hline \multirow{2}{*}{ Item } & \multicolumn{2}{|c|}{$\mathrm{CC}^{1}$} & \multicolumn{2}{|c|}{$\mathrm{FCR}^{2}$} & \multirow{2}{*}{$\mathrm{SEM}^{7}$} \\
\hline & $\mathrm{UCC}^{3}$ & $\mathrm{FCC}^{4}$ & $\mathrm{UFCR}^{5}$ & $\mathrm{FFCR}^{6}$ & \\
\hline Cyanide $\left(\mathrm{mg} \mathrm{kg}^{-1}\right)$ & $3.4^{\mathrm{a}}$ & $0.5^{\mathrm{a}}$ & $68.6^{\mathrm{b}}$ & $47.3^{c}$ & 0.88 \\
\hline Lysine g $100 \mathrm{~g}^{-1}$ protein & $3.8^{\mathrm{a}}$ & $8.5^{\mathrm{b}}$ & $3.9^{\mathrm{a}}$ & $5.5^{\mathrm{c}}$ & 0.53 \\
\hline $\mathrm{Ca}\left(\mathrm{g} \mathrm{kg}^{-1}\right)$ & 1.35 & 0.9 & 1.31 & 1.26 & 1.5 \\
\hline $\mathrm{P}\left(\mathrm{g} \mathrm{kg}^{-1}\right)$ & 0.7 & 0.64 & 0.73 & 0.69 & 0.6 \\
\hline
\end{tabular}

Means with different superscripts differ $(p<0.01),{ }^{1} \mathrm{CC}=$ Cassava chip, ${ }^{2} \mathrm{FCR}=$ Fresh cassava root pulp, ${ }^{3} \mathrm{UCC}=$ Unfermented cassava chip, ${ }^{4}$ FCC $=$ Fermented cassava chip, ${ }^{5}$ UFCR $=$ Unfermented fresh cassava root pulp, ${ }^{6} \mathrm{FFCR}=$ Fermented fresh cassava root pulp, ${ }^{7}$ Standard error of the mean.

in cassava fermentation during processing (Tweyongyere \& Katongole, 2002).

Cassava fermentation with $S$. cerevisiae resulted in a higher lysine content than those in unfermented cassava (Table 2). This indicate that the increase in lysine content of the cassava mash was a result of solid and liquid fermentation in which further increased the number of the yeast cells in cassava mash. Working with a mixed culture of the cellulolytic fungus Trichoderma viride and the yeast Candida utilis, Adebawo et al. (2000) and Toshihiro et al. (2007) used acid and alkali treatment, and gamma irradiation in which amino acids were found to be enhanced. In contrast, $\mathrm{Ca}$ and $\mathrm{P}$ contents were not changed, are in agreement with the ones reported by Akindahunsi et al. (1999).

\section{CONCLUSION}

The baker's yeast, a cheap and non-pathogenic microorganism used in this study, could efficiently increase the protein and lysine contents of CC and reduced the level of cyanide by fermentation. Therefore, yeast fermentation, especially in cassava root pulp and cassava chip, could potentially be used to enhance their nutritive value as animal diets, especially their protein and mineral contents of these products.

\section{ACKNOWLEDGEMENTS}

To the Office of Atoms for Peace (IAEA), Ministry of Science and Technology, Thailand, Tropical Feed Resources Research and Development Center (TROFEC), Department of Animal science, Faculty of Agriculture, Khon Kaen University, Thailand for providing research funds and facilities.

\section{REFERENCES}

ADEBAWO, O.O.; AKINGBALA, J.O.; RUIZ-BARBA J.L; SILESI, O.O. Utilization of high lysine-producing strains of Lactobacillus plantarum as starter culture for nutritional improvement of ogi. Applied Microbiology and Biotechnology, v.16, p.451455, 2000

AKINDUMILA, F.; GLATZ, B.A. Growth and oil production of apiotrichum curvatum in tomato juice. Journal of Food Protection, v.61, p.1515-1517, 1998.

AKINDAHUNSI, A.A.; OBOH, G.; OSHODI, A.A. Effect of fermenting cassava with Rhizopus oryzae on the chemical composition of its flour and gari. Rivista Italiana delle Sostanze Grasse, v.76, p.437- 440, 1999.

ANTAI, S.P.; MBONGO, P.N. Utilization of cassava peels as substrate for crude protein formation. Plant Foods for Human Nutrition, v.46, p.345-351, 1994. 
ARAUJO, L.F.; SILVA, F.L.H.; BRITO, E.A.; OLIVERA JUNIOR, S.; SANTOS, E.S. Enriquecimento protéico da palma forrageira com Saccharomyces cerevisiae para alimentação de ruminantes. Arquivo Brasileiro de Medicina Veterinária e Zootecnia, v.60, p.401-407, 2008.

ASSOCIATION OF OFFICIAL ANALYTICAL CHEMISTS AOAC. Official methods of analysis, 16 ed. Gaithersburg: AOAC., Gaithersburg, 1997. 202p.

BRADBURY, J.H. Simple wetting method to reduce cyanogen content of cassava flour. Journal of Food composition and Analysis, v.19, p.388-393 , 2006 .

CARDOSO, A.P.; ESTEVAO, M.; MARIO, E.; FERNANDO, M.; JULIE, C.; HAQUE, M.R.; BRADBURY, J.H. Processing of cassava roots to remove cyanogens. Journal of Food Composition and Analysis, v.18, p.451-460, 2005.

CHINHARD, F.P.; Photometric estimation of proline and orinithine. Journal Biological Chemistry, v.199, p.91-95, 1952.

CORREIA, R.; MAGAlHAES, M.; MACEDO, G. Protein enrichment of pineapple waste with Saccharomyces cerevisiae by solid state bioprocessing. Journal of Scientific \& Industrial Research, v.66, p.259-262, 2007.

CUMBANA, A.; MIRIONE, E.; CLIFF, J.; BRADBURY, J.H. Reduction of cyanide content of cassava flour in Mozambique by the wetting method. Food Chemistry v.101, p.894-897, 2007.

FAGBEMI, A.O.; IJAH, U.J.J. Microbial population and biochemical changes during production of protein-enriched fufu. World Journal of Microbiology \& Biotechnology, v.22, p.635640, 2006.

LAMBERT, J.L.; Ramasamy, J.; Paukstelis J.V. Stable reagents for calorimetric determination of cyanide by modification Konig reaction. Analytical Chemistry, v.47, p.916-918, 1975.

LOWRY, 0.H.; ROSENBROUGH, N.J.; FARR, A.L.; Randall, R. Enhanced alkaline copper protein assay. Journal Biological Chemistry, v.193, p.265-271, 1951.

LEHNINGER, A.L.; Bioenergetics and metabolism, principle of biochemistry, 2 ed.. New Delhi: CBS Publishers \& Distributors, 1987.

OBOH, G. Nutritional, toxicological and by-products utilization potentials of micro-fungi fermented cassava (Manihot esculenta, Crantz) tuber roots. Akure: Federal University of Technology, 2002. Thesis (PhD).

OBOH, G. Nutrient enrichment of cassava peels using a mixed culture of Saccharomyces cerevisiae and Lactobacillus spp solid media fermentation techniques. Electronic Journal of Biotechnology, v.9, p.46-49. 2006.

OBOH, G.; AKINDAHUNSI, A.A. Biochemical changes in cassava products (flour \& gari) subjected to Saccharomyces cerevisiae solid media fermentation. Food Chemistry, v.82, p.599-602, 2003.

OBOH, G.; AKINDAHUNSI, A.A. Nutritional and toxicological evaluation of Saccharomyces cerevisiae fermented cassava flour. Journal of Food Composition and Analysis, v.18, p.731738, 2005.
OBOH, G.; AKINDAHUNSI, A.A.; OSHODI, A.A. Nutrient and anti-nutrient contents of Aspergillus niger-fermented cassava products (Flour and Gari). Journal of Food Composition and Analysis, v.15, p.617-622, 2002.

PADMAJA, G.; GEORGE, M.; MOORTHY, S.N. Detoxification of cassava during fermentation with a mixed culture inoculum. Journal of the Science of Food and Agriculture, v.63, p.473-481, 1993.

SAS INSTITUTE. SAS/STAT ${ }^{\circledR}$ user's guide (release 6.03). Cary: SAS Institute, 1988

SOEST, P.J. van; Nutritional ecology of the ruminant, 2 ed. Ithaca: Cornell University Press, 1994. 373p.

STUPAK, M.; VANDERSCHUREN, H.; GRUISSEM, W.; ZHANG, P. Biotechnological approaches to cassava protein improvement. Trends in Food Science \& Technology, v.17, p.634-641, 2006.

TOSHIHIRO, T.; FUKUDA, H.; KONDO, A. Production of LLysine from starch by Corynebacterium glutamicum displaying $\alpha$-amylase on its cell surface. Applied Microbiology and Biotechnology, v.74, p.1213-1220, 2007.

TWEYONGYERE, R.; KATONGOLE, I. Cyanogenic potential of cassava peels and their detoxification for utilization as livestock feed. Veterinary and Human Toxicology, v.44, p.366-369, 2002.

VENDRUSCOLO, F.; da SILVA RIBBEIRO, C.; ESPOSITO, E.; NINOW, J.L. Protein enrichment of apple pomace and use in feed for Nile Tilapia. Journal of Applied Biochemistry and Biotechnology, v.152, p.74-87, 2009.

WANAPAT, M.; PIMPA, O.; SRIPUEK, W.; PURAMONGKOL, T.; PETLUM, A.; BOONTAO, U.; WACHIRAPAKORN, C.; SOMMART, K.; Brooker, J.D. Cassava hay: an important onfarm feed for ruminants. In: TANNINS IN LIVESTOCK AND HUMAN NUTRITION. Proceedings. Adeleaide: CABI International, 1999. p.71-74.

WANAPAT, M. Manipulation of cassava cultivation and utilization to improve protein to energy biomass for livestock feeding in the tropics. Asian-Australasian Journal of Animal Science, v.16, p.46-52, 2003.

WANAPAT, M.; PROMKOT, C.; WANAPAT, S. Effect of cassoyurea pellet as a protein source in concentrate on ruminal fermentation and Digestibility in Cattle. Asian-Australasian Journal of Animal Science, v.19, p.1004-1009, 2006.

WANAPAT, M.; KHAMPA, S. Effect of levels of supplementation of concentrate containing high levels of cassava chip on rumen ecology, microbial $\mathrm{N}$ supply and digestibility of nutrients in beef cattle. Asian-Australasian Journal of Animal Science, v.20, p.75-82, 2007.

Received March 04, 2008 Accepted March 23, 2009 